\title{
Resilient Regions from Sustainable Development Perspective
}

\author{
Mariann Szabó ${ }^{1}$, Mária Szalmáné Csete ${ }^{1}$, Tamás Pálvölgyi ${ }^{1}$
}

\begin{abstract}
Regional economies in today's world of transitions experience different kinds of shocks: economic downturn, industry shocks which influence the path and pattern of regional economic growth, the quality of life of the inhabitants as well as the state of built and natural environment. Originated from ecological and psychological sciences the term 'resilience' describes the capability to adapt and renew under unfavourable conditions while regional resilience is determined how the region or system responds to shock or disturbance and under these circumstances able to ensure its continuous development. Continuous development criterion links regional resilience to sustainable development (improve the lives of people round the World) promoted by the 2030 Agenda for Sustainable Development and its 17 Sustainable Development Goals. Developing criteria for resilient regions for promoting sustainable development could contribute to more complex comprehension of regions in spatial development. The research, although put emphasis on economic viability regions are handled as complex systems of various institutional aspects, natural and man-made resources and society, which state, flexibility influences the adaptive capacity of regions to high extent.
\end{abstract}

Keywords: Resilient Regions, Sustainable Development, Spatial Development, Sustainable Development Goals, Adaptive Capacity

\section{Introduction}

In recent times due to the ongoing changes in the economy on global scale affects all components of local economies around the World. The various effects of global economic crisis on regional level called the attention to the resilience of regions: why one region is more vulnerable to economic shock than other resulted to analyse resilience notion in regional development context (Palekiene et al., 2015). Originated from environmental and disaster studies the term 'resilience' describes the capability to adapt and renew under unfavourable conditions; parallel to the growing number of specific extraordinary events and shocks in global economy the importance of phenomena has increased in regional sciences with special interest to regional adaptation. As Palekiene et al. (2015) points out, despite its importance, there is no universally agreed definition of regional resilience, as well as there is yet no theory of regional resilience as such, which might be due to the fact that as there is lack of common understanding in regional science how regions develops, consequently the concept of resilience could not be a uniformed notion neither. Nevertheless, as Christopherson et al. (2010) describes -in a special issue of Cambridge Journal of Regions, Economy and Society devoted to examining regional resilience- for analysing regional resilience the concepts of 
adjustment and adaptation have high relevance: for an economically successful region, the likelihood of success being sustained over the long term will depend crucially on its ability to adapt to changing circumstances over time and to adjust to external shocks as and when these occur. From this description it is evident that the long-term viability of regions depends on their adaptive capacity. As sustainable development, an integrated approach calls the attention to regions for a convergence between economic, social and environmental and human dimensions, (with special regard on the institutional and personal aspects crucial for its regional realization) is strongly associated with the question of regional resilience since both concepts are dedicated for enhance regions' long-term viability.

Despite their connectivity small efforts have been made examining the relationship between sustainable development and regional resilience which would be due to that the environmental aspects of regional development are rarely taken into consideration since regional science is devoted for explaining the different development path of regions, the effect of various economic policies (for e.g. import substitution, export promotion, liberalization of markets) on development, persistent differences in social welfare across regions (Armstrong, 1995; Bhagwati - Krueger, 1973; Dawkins, 2003), while sustainable development programmes addresses enterprises (for instance let's see UN Global Compact, the world's largest corporate sustainability initiative, a call to companies to align strategies and operations with universal principles on human rights, labour, environment and anti-corruption, and take actions that advance societal goals) or smaller territorial units (Local Agenda 21 Program) while the aims cover the entire world (On 1 January 2016, the 17 Sustainable Development Goals (SDGs) of the 2030 Agenda for Sustainable Development — adopted by world leaders in September 2015 at an historic UN Summit - officially came into force).

As previously has been described there is neither universal definition nor unique model of regional resilience. The main objective of our research is to deepen the comprehension on regional resilience by providing a framework for analysis from sustainable development perspective. Further aim of our research is to demonstrate the relation between the adaptive capacity of a city region and sustainable development since on long run a region is considered as resilient if it provides opportunity for further generations to satisfy their needs. For proving this an evaluation system of sustainability for regional resilience analysis is developed. As Simmie and Martin (2010) apply the ecological model of 'adaptive cycles' for city-region areas of Cambridge and Swansea proving that regional resilience could be examined on this territorial level, in our research we focus on the development of a Hungarian city-region, Szeged, centre of the Southern Great Plain NUTS-2 region, a higher-education centre. We apply the resilience analysis for this city region, as the settlement operates as an economic pole (resembles to the theory, called 'Growth Pole Theory' by Francois Perroux in the 1950s, which essence is that growth is not uniform in different places but growth has different degrees of intensity in different point, or poles, and then it spreads via channels and its final result for the state economy is different in different regions where the key players are those industries, enterprises or other institutions which are able to stimulate economic development in linked businesses and industries through productive consumption as Csete, M., Szabó, M., 2015 describes). 


\section{Literature Review}

The importance of regions-conceptualized as a unit of social-economic space, characterized by production structure of all ownership forms, population, employment concentration as well as governmental institutions, fundamentally, a social, cultural, political and economic interaction system (Agnew, 2000, 2001; Haukkala et al., 1999 in Palekiene et al., 2015)- ascends in nowadays' economy. Meanwhile regional and local economic development is far from a smooth and incremental process, instead, as Simmie and Martin (2010) notes it is the subject to all sorts of interruptions and disruptions, like periodic economic recessions, the unpredictable rise of major competitors elsewhere, unexpected plant closures, the challenges arising from technological change and like, and the state responses answering these challenges and the degree of decentralization and the adaptive capacity of territories differs to high extent even in the same national economy. A resilient region is more than a territory which is successful at economic development (although the importance of economic viability is not evitable for population retention purposes), rather it is one which is capable to maintain economic success over the long term in face of the inevitable adaptation required by changes in international competition, shifts in consumer demand and other such 'shocks' to the system (Christopherson et al., 2010). But then, which factors enable a region to adjust and adapt over time? A strong regional system of innovation (Clark et al., 2010; Howells, 1999 in Christopherson et al., 2010), strength in factors that create a 'learning region' (Archibugi and Lundvall, 2001 in Christopherson et al., 2010), modern productive infrastructure (transport, broadband provision, etc.), skilled, innovative and entrepreneurial workforce, supportive financial system providing patient capital and finally a diversified economic base, not over-reliant on a single industry (Christopherson et al., 2010). Income level could not obviously explain the adaptive capacity of regions although without favourable local market conditions and structure regions lose from their economic power and consequently from their attractiveness.

After that, it might be not surprising that Simmie and Martin (2010) interpret resilience as 'adaptive ability' since it is the differential ability of a region's or locality's firms to adopt to changes and shocks in competitive, market, technological, policy and related conditions that shape the evolutionary dynamics and trajectories of that regional or local economy over time. 'Adaptive capacity' and 'adaptive ability' are linked notions: the capacity of the region (the economic, social, environmental and institutional resources) determines the local economy's resilience. In the literature the main two discursions over resilience exist: the notion of engineering resilience where the more resilient the economy is if the less it would change over time, even in the face if various shocks; while ecological resilience focuses on whether disturbances and shocks cause a system to move into another regime of behaviour (Christopherson et al., 2010; Simmie and Martin, 2010). Palekiene et al. (2015) describes multidimensional aspects of regional resilience notion as well as prove that resilience has a dynamic feature insured regional uninterrupted development or fast enough recovery after economic shock occurred, as well as interpret regional resilience capacity building factors. Considering regions as systems (systems perspective), regional resilience is conceived both as a process linking a set of adaptive capacities (social, economic, infrastructure capital, etc.) to overcome 
shock and outcome when region accepted undergoing adaptive changes to its economic structure by transiting into new sustainable growth path. Considering the ecological resilience approach regional resilience comprises two dimensions: the extent to which the regions' economy declines and the speed or time required to return to the pre-shock growth path, meaning that the two main measure of regional resilience is speed and time (Palekiene et al., 2015). Martin (2012) interprets four alternatives -interrelated dimensions- which fully and precisely describe regional economic resilience's respond to shock: resistance, recovery, re-orientation and renewal. On the first hand, resistance is the property indicates the initial impact of the shock (equal to the depth of the reaction of regional economy to shock), on the second and, recovery indicates the speed of bounce back and determined by the degree of resistance to the shock at the first moment (the specific path to which the region recovers), on the third hand re-orientation, measuring the extent to which region adapts it's economic structure or re-orientated and on the last hand renewal: the degree resumption of the region economy's growth path before the shock occurred. Besides resistance, recovery, re-orientation and renewal Tu \& Chen (2013) emphasize the importance of robustness (the ability of a system to preserve its structure in the face of disturbance) or with other words according to Bruneau et al. (2003) that the strength elements of the system in order to withstand external pressure without suffering any loss, meanwhile Van der Veen \& Logtmeijer (2005) points out redundancy (the ability of the system to respond to disturbance by overcoming dependence by deferring, using substitutes or even relocating), Bruneau et al. (2003) resourcefulness: the capacity to mobilize and apply material and human resources to achieve goals in the events of disruptions parallel to Buckle et al. (2000) declaring that the local availability of resources and skills may be directly relevant to emergency management, planning, preparedness in disruptive situation and Palekiene et al. (2015) put emphasis on rapidity as important properties of regional resilience. Often referred as the main dimensions of resilience, robustness, redundancy, resourcefulness and rapidity are called as $4 \mathrm{R}$ approach, which significance is that it highlights the multiple paths to resilience and directs to look beyond physical and organizational systems to the impact of the chock on social and economic systems (Palekiene et al., 2015). The 4R approach is also used in context of climate change resilience by using adaptive capacity in formalization of regional or local vulnerability (Pálvölgyi et al, 2011). In system view; as the region consists of many different components, combined in various forms of relationships, regional resilience is identified as the capacity of all components' in the sum to withstand and recover from the shock from ecological interpretation of regional resilience validates the importance of adaptive capacity in long-term development. As we can see, the ecological interpretation links the idea of resilience with adaptability: as McGlade et al. (2006) describes the approach is much richer in evolutionary scope (McGlade et al., 2006 in Simmie and Martin, 2010).

Nowadays, the growing attention to regions, is due to the persistent differences in levels of social welfare (increasing quantity of material goods, increasing level of incomes, more diversified consumption structure of inhabitants), or social well-being (social welfare adjusted with such problematically measurable or non-material dimensions as happiness or self-satisfaction and the quality of the natural environment). Differences derived from that space has an impact on processes driving innovation and national economic growth 
(in reference to one of the main statements of regional economics / science, that "space matters") accordingly regions must be handled as systems with specific components. These components are local natural resources, energy portfolio, local culture, the availability and quality of human resource other location-specific amenities, economic activity and performance, region-specific so called endogenous technology level, the intra-regional and extra-regional cooperation intensity (enhancing technology-transfer and innovation, and access to exogenous technology) which all influence the adaptive capacity of regions facing the challenges derived from globalization, activity of transnational enterprises (those economic power is stronger than national economies in specific cases), the direct and irresistible effects of global financial system on global economy, the unification of consumer behaviour and consumption patterns (with respect to demonstration, and status-quo), emergence of regional integrations and commercial blocks affecting economic viability. (Dawkins, 2003)

As we can conclude, economic viability is the common point between sustainable development and regional resilience, continuous development criterion links them. The most wide-known definition of sustainable development comes from 'Our Common Future'; a report published by the World Commission on Environment and Development in 1987; saying sustainable development is a form of development which: 'meets the needs of the present without compromising the ability of future generations to meet their own needs' (WCED, p. 43). We can easily realize that sustainable development and environmental resource allocation has strong relations; consequently we can distinguish two levels of sustainability. Weak sustainability allows the substitution of natural resources with another type of resource. Man-made and natural capital is substitutable, but the sum must be non-declining. Strong sustainability is when we do not allow the value of natural resources to be reduced; each stock must be non-declining separately. Sustainable development calls the convergence between the three pillars of economic development, social equity, and environmental protection. The main challenge of the first pillar: economic development is to manage and maintain current economic system in that way that we can live off the dividends of our resources. As described before, a region has various resources - capital when economic development comes to the picture: financial-, manufactured-/ durable-, human- (stocks of learned skills), intellectual(accumulation of knowledge and skills not embodied in individuals), social- (set of institutions and customs) and natural capital (both renewable and non-renewable). Concerning the second pillar, social equity the main challenges is to achieve distributional equity, adequate provision of social services including health and education, gender equality and political accountability and participation, while the third pillar, environmental protection means requires do not overwhelm the waste assimilative ability of the environment nor the regenerative services of the environment, deplete nonrenewables only to the extent we invest in renewable substitutes. Sustainable development in regional context means the protection the environment and at the same time fulfilling economic and social objectives, where each region should meet the following three operational criteria: economic objectives should not be maximized without satisfying environmental and social constraints (1), environmental benefits should not be maximized without satisfying economic and social constraints (2) and finally social benefits should not be maximized without satisfying economic and 
environmental constraints (3). (Drexhage et al., 2010)

The 17 Sustainable Development Goals (SDGs) of the 2030 Agenda for Sustainable Development (adopted by world leaders in September 2015 at an historic UN Summit) came into force officially on 1 January 2016, call the attention and apply to all countries to mobilize efforts to end all forms of poverty, fight inequalities and tackle climate change, while ensuring that no one is left behind. The goal system as a framework indicates the importance of regions in realizing sustainable development perspective. The Goals have been set call the attention for cooperation which is important from resilience point of view too: without appropriate level of cooperation between the public and private sector each area is more vulnerable to various shocks (let us just consider the problem of plant closure which could have large impact on economic development especially when local economy is far from diversification). The realization of the Goals requires different efforts from the States but contributes to improve their adaptive capacity, namely:

1. 'End poverty in all its forms everywhere',

2. 'End hunger, achieve food security and improved nutrition, and promote sustainable agriculture',

3. 'Ensure healthy lives and promote wellbeing for all at all ages',

4. 'Ensure inclusive and equitable quality education and promote lifelong learning opportunities for all',

5. 'Achieve gender equality and empower all women and girls',

6. 'Ensure availability and sustainable management of water and sanitation for all',

7. 'Ensure access to affordable, reliable, sustainable and modern energy for all',

8. 'Promote sustained, inclusive and sustainable economic growth, full and productive employment, and decent work for all',

9. 'Build resilient infrastructure, promote inclusive and sustainable industrialisation, and foster innovation',

10. 'Reduce inequality within and among countries',

11. 'Make cities and human settlements inclusive, safe, resilient and sustainable',

12. 'Ensure sustainable consumption and production patterns',

13. 'Take urgent action to combat climate change and its impacts',

14. 'Conserve and sustainably use the oceans, seas and marine resources for sustainable development',

15. 'Protect, restore and promote sustainable use of terrestrial ecosystems, sustainably manage forests, combat desertification and halt and reverse land degradation, and halt biodiversity loss',

16. 'Promote peaceful and inclusive societies for sustainable development, provide access to justice for all and build effective, accountable and inclusive institutions at all levels', 17. 'Strengthen the means of implementation and revitalise the global partnership for sustainable development'. (UN SDKP, online)

A good answer would be the acceptance and realization of strategies on national level which goals' structure is harmonized by the global ones. For instance, National Framework Strategy on Sustainable Development of Hungary was accepted in order to promote sustainable development, the possibilities of future generations and the long term responsible management of natural resources. The strategy emphasizes that there 
are four primary resources that need to be sustained: besides the identified three interconnected and interdependent dimensions of sustainable development: economic, social and environmental the social dimension with the human one must be complemented. Both Goal 9 and 11 indicates the importance of resilience from sustainability perspective, which supports our statement that long-term viability is the attachment between Sustainable Development and regional resilience. After the literature review and demonstration of that the SDGs prove the importance of resilience in territorial development we introduce an evaluation system of sustainability for regional resilience analysis. As mentioned before neither universal definition nor model of regional resilience exists; we would like to deepen the comprehension on regional resilience by providing a framework for analysis from sustainable development perspective.

\section{Methodology}

At first we introduce our case study city region: we interpret the situation of the city of Szeged nowadays then review its history focusing on shocks which influenced its long-term development patterns. After that we interpret the evaluation system of sustainability for regional resilience analysis we made. Based on the monographs of the city, factors has been collected and sorted into a framework. We have assessed eight historical periods (Roman Empire, Period between the Roman Empire and Hungarian conquest, The Hungarian conquest and the Árpád Dynasty (9th-13 ${ }^{\text {rd }}$ Century), the $14^{\text {th }}$ $15^{\text {th }}$ Century, Ottoman Empire, the 18 ${ }^{\text {th }}-19^{\text {th }}$ Century, Period after the World War I, and the Period after the World War II.) and we have identified development factors according to the sustainable development pillars (environment- economy- society) completed with the institutional system. The result of the research is a systematic comparison of the city concerning the environment (local energy, potential energy, environmental impacts, and built environment), economy (economic growth/development, prerogatives, knowledge, supply, capital, and alteration), society (dominant societal groups, employment, features, culture, and education), and institutional system (government, titles). Based on the results of the research a graphical demonstration has been elaborated, which shows the development fields of the city by historical ages.

The research describes the different work cultures, the change of trends in trade, manufacturing due to the economic circumstances' variability. To keep the research focused we reviewed those factors, which affected the urbanization to high extent, this is the reason why the agricultural and rural development is less emphasized. The two main focus points of the historical development are the period after the Austro-Hungarian Compromise of 1867 (widely accepted that it is the beginning of the Hungarian spatial development), and the Socialist system and its collapse in 1989.

Szeged city region

Szeged, situated next to River Tisza (one of the most dominant rivers in the country) a city with 162,621 inhabitants according to the Hungarian Statistical Office, is the centre of basically agriculture-oriented NUTS-2 Southern Great Plain Region, a less developed region in Hungary (the general income inequality pattern in Hungary is often called as 
the emergence of the 'West-East declination' since, due to its closeness to foreign countries Western Transdanubia region's situation is more agreeable and the economic hegemony of the capital is not questionable) considering the GDP/capita or the concentration of the foreign-owned enterprises' capital is the third biggest city in the country. As regional centre the city -which economy is quite favourable- it has dominant the educational/touristic/cultural/commercial role, in line with the R\&D\&I activity. The favourable economic situation of the city nowadays is due the presence of the university and its capability for attracting students from abroad whose purchasing parity provides opportunity for the establishment of new businesses. According to the results of the last population census took place in $201141.2 \%$ of the city is employed, $4.7 \%$ is unemployed, dependents are $27 \%$ and inactive beneficiaries of subsidies are $27.1 \%$ of the total population. In 2011, 23\% worked in education, 19\% worked in industry, and $15.5 \%$ worked in government, $10 \%$ in commerce, $9 \%$ in transportation and warehousing, 2-2$2 \%$ in agriculture / building industry / health services and $17.5 \%$ in other economic braches of the active population.

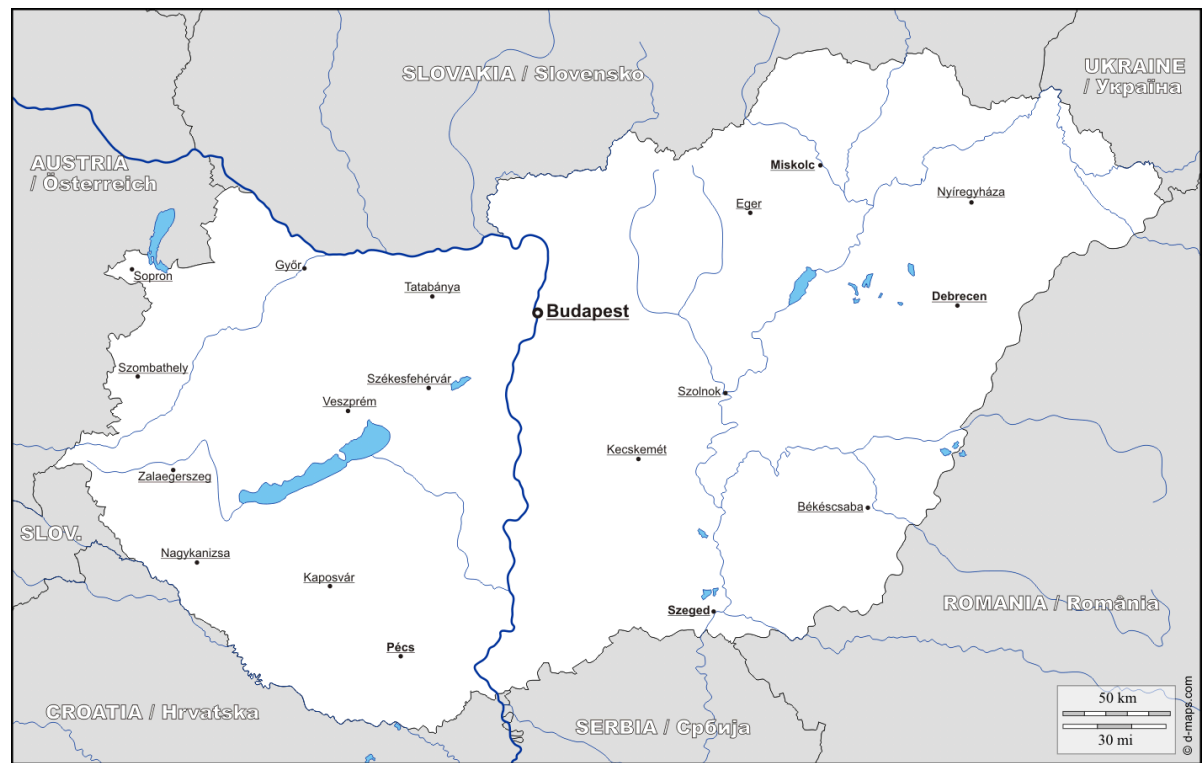

Figure 1: Location of Szeged (source: http:/ / d-maps.com/)

\section{History}

Monographs describing the development of the city states that territory was inhabited B.C. The development of the settlement until the Hungarian Conquest (895) mainly was linked to governmental issues. At the age of the Hungarian Conquest and the Árpád Dynasty the settlement prospered, new ways of economic activities were introduced, the development were in line with the growth of its commercial importance. During the $14^{\text {th }}$ $-15^{\text {th }}$ Century Szeged become an international exporter after that the Royal free city title was given.

The development of the $14 \mathrm{t}^{\mathrm{h}}-15^{\text {th }}$ Century was fractured by the Ottoman Conquest, 
which is the first significant external-forced path-diversion. A protection zone was built in Szeged; the city did not suffer the regime's change like other ones.

Development of Szeged in the $18^{\text {th }}$ Century was due to the improvement of cultural circumstances. The majors of the town invited the Piarists, who founded school, acclimatized the theatre-games, and provided knowledge. Szeged's importance as a trade centre was exponentially growing: in 1845 the regular shipping on river Tisza began (Reizner, J., 1899), the railway line was built by 1854 between Pest (capital of Hungary) and Szeged, and later on the Szeged - Temesvár (Timisoara, Romania) line, too (Daragó, S., 2008). This period was the real age of capitalism: several new factories were founded, the traditional pepper-manufacturing shifted into factorial production. The traditional factory of Szeged, namely, the Pick Factory (food factory, salami-production) was developed from and little manufacturing unit to a worldwide-known institution. This time the hemp spinning factory of Nándor, Bakay was founded. The factory did not survived after the collapse of the Socialism, nowadays one part of the factory's building works as a shopping mall, near to the city centre. The great flood of 1879, which literally wiped away the whole town, caused a pause in the city's development, but later on the reconstruction of the city resulted a radial urban structure, and the city was given a residential character (Daragó, S., 2008). The stable political situation derived from the Austro-Hungarian Compromise of 1867 affected the smooth development of the city. During the period the tram public transport mode was introduced and with the new settlement structure the developments in transport are well-designed since nowadays on. After the World War I, economic recession hit the city; the university-city title encouraged its development.

During the Socialist System, Hungary has been charged with heavy industrial production. Szeged's role was less significant from heavy industrial point of view, nevertheless a few new factories were founded, and immigration flows occurred. New industrial branches naturalized in the city, the textile-industry, math-production, cable-production, rubberproduction, furniture-production. In 1965 hydrocarbon fields were discovered, which had a push effect of oil zone's development. After the collapse of Socialist System many of the factories founded was closed after 1989, due to both by losing stable markets, and the economic decision-makers' limited rationality (intention to not stay connected with Russia). Szeged nowadays has its industrial potential in food-and chemical industry, as the textile-, cable-, furniture-, hemp spinning-, not even the pepper-manufacturing was able to stay in the global competition. The other pillar of Szeged's economy is the educational/touristic/cultural role, in line with the R\&D\&I activity. (Daragó, S., 2008)

Evaluation system of sustainability for regional resilience analysis

By the review we will recognize the factors influenced its development and that how the factors were changing during history, as we know, that factors triggers development in territories can loose from their significance in long turn.

The next figure shows the evaluation criteria used to assess the development of the city. The dimensions are composed of the sustainable developments' pillars completed with the institutional system. 
Table 1: Description of the evaluation categories for the regional resilience analysis (source: own compilation)

\begin{tabular}{|c|c|c|c|}
\hline $\begin{array}{l}\text { Sustainable } \\
\text { development } \\
\text { pillars }\end{array}$ & No. & Category & Description \\
\hline \multirow{4}{*}{ Environment } & 1 & local resources & $\begin{array}{l}\text { They are those important resources, features from which } \\
\text { urban systems take benefits. Local energies influence the land } \\
\text { use of enterprises, urban networks and influence the } \\
\text { economic structure of regions. }\end{array}$ \\
\hline & 2 & $\begin{array}{l}\text { potential or } \\
\text { positional } \\
\text { resources }\end{array}$ & $\begin{array}{l}\text { Those resources, benefits which ensure advantageous position } \\
\text { for urban systems. They are usually man-made but their } \\
\text { benefit is comprehended in urban context, for instance a } \\
\text { railway network's potential energy is good availability. }\end{array}$ \\
\hline & 3 & $\begin{array}{l}\text { environmental } \\
\text { impacts }\end{array}$ & $\begin{array}{l}\text { The economic activity of urban systems, the various outputs } \\
\text { have different effects on natural environment. }\end{array}$ \\
\hline & 4 & built environment & The components, physical elements if urban systems. \\
\hline \multirow{6}{*}{ Economy } & 1 & $\begin{array}{l}\text { economic } \\
\text { development }\end{array}$ & $\begin{array}{l}\text { Describes the main economic profile of the settlement, } \\
\text { progress of income generation and conditions of wealth. }\end{array}$ \\
\hline & 2 & prerogatives & $\begin{array}{l}\text { Prerogatives are titles, privileges that provides special } \\
\text { importance, role for the settlement. }\end{array}$ \\
\hline & 3 & knowledge & $\begin{array}{l}\text { Different sources, players who embody special knowledge } \\
\text { base and contributes to local or regional development. }\end{array}$ \\
\hline & 4 & supply & New forms of economic activity, new markets. \\
\hline & 5 & capital & Financial background for economic development. \\
\hline & 6 & alteration & Changes in the role of the urban system. \\
\hline \multirow{5}{*}{ Society } & 1 & \begin{tabular}{|l|}
$\begin{array}{l}\text { dominant societal } \\
\text { groups }\end{array}$ \\
\end{tabular} & $\begin{array}{l}\begin{array}{l}\text { Dominant societal groups form the local economic } \\
\text { atmosphere. }\end{array} \\
\end{array}$ \\
\hline & 2 & employment & Employment structure and features of the location. \\
\hline & 3 & features & Specialities of the community. \\
\hline & 4 & culture & Cultural patterns of the city. \\
\hline & 5 & education & Educational developments, progress. \\
\hline \multirow{2}{*}{$\begin{array}{l}\text { Institutional } \\
\text { system }\end{array}$} & 1 & government & $\begin{array}{l}\text { Governmental patterns, role of the settlement in various } \\
\text { spatial networks. }\end{array}$ \\
\hline & 2 & titles & Titles given to the settlement for various purposes. \\
\hline
\end{tabular}

In the next section we carry out the analysis for the city region. From Table 2 to Table 5 we highlight the main factors of the development of the city region by the dimensions. Later we aggregate the results and interpret a graphical demonstration of the development through the historical ages (Table 6.). Ensuring better transparency, we numbered the factors and in the aggregate matrix (Table 6) we indicate them. The matrix structure helps us to overview in which period which pillar was influential in the development of the settlement. In the analysis, we highlight the most influential factors by connecting historical ages. 


\section{Results: Introduction of the Evaluation System of Sustainability for Regional Resilience Analysis}

Table 2: Evaluation system of sustainability for regional resilience analysis - dimension 'Environment' (source: own compilation)

\begin{tabular}{|c|c|c|c|c|}
\hline & \multicolumn{4}{|l|}{ Environment } \\
\hline & $\begin{array}{l}\text { 1. local } \\
\text { resources }\end{array}$ & $\begin{array}{l}\text { 2. potential or } \\
\text { positional } \\
\text { resources }\end{array}$ & $\begin{array}{l}\text { 3. environmental } \\
\text { impacts }\end{array}$ & 4. built environment \\
\hline Roman Empire & 1.1 location & $\begin{array}{l}2.1 \mathrm{road}- \\
\text { courier services }\end{array}$ & & \\
\hline $\begin{array}{l}\text { The Hungarian } \\
\text { conquest and } \\
\text { the Ârpád } \\
\text { Dynasty ( } 9^{\text {th }}-13^{\text {td }} \\
\text { Century) }\end{array}$ & 1.1 location & $\begin{array}{l}2.2 \text { road } \\
\text { junctions }\end{array}$ & & \\
\hline $\begin{array}{l}\text { The } 14^{\text {th }}-15^{\text {th }} \\
\text { Century }\end{array}$ & $\begin{array}{l}1.1 \text { location, } \\
1.2 \text { agricultural } \\
\text { conditions }\end{array}$ & $\begin{array}{l}2.2 \text { road } \\
\text { junctions }\end{array}$ & & $\begin{array}{l}4.1 \text { ground castle - } \\
\text { protection of the town }\end{array}$ \\
\hline $\begin{array}{l}\text { Ottoman } \\
\text { Empire }\end{array}$ & & & & $\begin{array}{l}4.2 \text { castle's } \\
\text { modernization }\end{array}$ \\
\hline $\begin{array}{l}18^{\text {th }}-19^{\text {th }} \\
\text { Century }\end{array}$ & $\begin{array}{l}\text { 1.1 location, } 1.3 \\
\text { River Tisza }\end{array}$ & $\begin{array}{l}\text { 2.3 shipping, } \\
\text { 2.4 Pest - } \\
\text { Szeged railway, } \\
\text { 2.5 Szeged - } \\
\text { Temesvár } \\
\text { railway line }\end{array}$ & $\begin{array}{l}3.1 \text { negative external } \\
\text { impacts on society due } \\
\text { to the operation of the } \\
\text { starch factory and bone } \\
\text { meal factory, } \\
3.2 \text { great flood's impact }\end{array}$ & $\begin{array}{l}4.3 \text { the town's } \\
\text { reconstruction after } \\
\text { the great flood, } \\
4.4 \text { residential city, } \\
4.5 \text { trams in the city }\end{array}$ \\
\hline $\begin{array}{l}\text { Period after the } \\
\text { World War II. }\end{array}$ & $\begin{array}{l}1.4 \text { agricultural } \\
\text { crops, } \\
1.5 \text { woods' } \\
\text { floating on River } \\
\text { Tisza, } \\
1.6 \text { clay, } \\
1.7 \text { hydrocarbon }\end{array}$ & & & $\begin{array}{l}4.6 \text { appearance of } \\
\text { large panel system } \\
\text { dwellings on a less } \\
\text { concentrated level } \\
\text { compared to other } \\
\text { Hungarian cities }\end{array}$ \\
\hline
\end{tabular}

Table 3: Evaluation system of sustainability for regional resilience analysis - dimension 'Economy' (source: own compilation)

\begin{tabular}{|c|c|c|c|c|c|c|}
\hline & \multicolumn{6}{|l|}{ Economy } \\
\hline & $\begin{array}{l}\text { 1. economic } \\
\text { development }\end{array}$ & 2. prerogatives & 3. knowledge & 4. supply & 5. capital & 6. alteration \\
\hline $\begin{array}{l}\text { Roman } \\
\text { Empire }\end{array}$ & $\begin{array}{l}1.1 \text { Roman guard (salt } \\
\text { and gold transportation } \\
\text { to South-Transylvania), } \\
\text { post town }\end{array}$ & & & & & \\
\hline $\begin{array}{l}\text { The } \\
\text { Hungarian } \\
\text { conquest } \\
\text { and the } \\
\text { Árpád } \\
\text { Dynasty } \\
\left(9^{\text {th-13 }} 13^{\text {rd }}\right. \\
\text { Century) }\end{array}$ & $\begin{array}{l}1.2 \text { commercial node, } \\
\text { storage (wood and salt } \\
\text { floated on River Maros), } \\
\text { building industry, then } \\
\text { craft industry }\end{array}$ & $\begin{array}{l}2.1 \text { The Golden } \\
\text { Bull (1222 King } \\
\text { Andrew II) } \\
\text { exclusive salt- } \\
\text { storage } \\
\text { privilege for } \\
\text { Szeged and } \\
\text { Szalócs, right to } \\
\text { have market }\end{array}$ & & $\begin{array}{l}4.1 \text { salt- } \\
\text { commerce }\end{array}$ & & \\
\hline $\begin{array}{l}\text { The } 14^{\text {th }}- \\
15^{\text {th }}\end{array}$ & $\begin{array}{l}1.3 \text { commerce, livestock } \\
\text { breeding, agriculture }\end{array}$ & $\begin{array}{l}2.2 \text { Royal free } \\
\text { city title and }\end{array}$ & & $\begin{array}{l}4.2 \text { connection } \\
\text { to }\end{array}$ & & \\
\hline
\end{tabular}




\begin{tabular}{|c|c|c|c|c|c|c|}
\hline & \multicolumn{6}{|l|}{ Economy } \\
\hline & $\begin{array}{l}\text { 1. economic } \\
\text { development }\end{array}$ & 2. prerogatives & 3. knowledge & 4. supply & 5. capital & 6. alteration \\
\hline Century & & $\begin{array}{l}\text { consequently } \\
\text { the centre of } \\
\text { the beef trade } \\
\text { toward Italy }\end{array}$ & & $\begin{array}{l}\text { international } \\
\text { trade }\end{array}$ & & \\
\hline $\begin{array}{l}\text { Ottoman } \\
\text { Empire }\end{array}$ & 1.4 commerce & & & & & \\
\hline $\begin{array}{l}18^{\text {th }}-19^{\text {th }} \\
\text { Century }\end{array}$ & $\begin{array}{l}1.5 \text { tobacco growing, } \\
\text { grain trade, shipping, } \\
\text { alcohol production, } \\
\text { salami production, } \\
\text { pepper fracture, hemp } \\
\text { spinning, textile } \\
\text { industry }\end{array}$ & & $\begin{array}{l}3.1 \text { Piarists, } \\
\text { factory } \\
\text { proprietors with } \\
\text { international } \\
\text { experience }\end{array}$ & $\begin{array}{l}4.3 \\
\text { international } \\
\text { trade of } \\
\text { paprika }\end{array}$ & $\begin{array}{l}5.1 \text { saving } \\
\text { bank of } \\
\text { Csongrád } \\
\text { county as } \\
\text { source of } \\
\text { capital }\end{array}$ & \\
\hline $\begin{array}{l}\text { Period after } \\
\text { the World } \\
\text { War I. }\end{array}$ & $\begin{array}{l}\text { 1.6 losing the economic } \\
\text { agglomeration area, } \\
\text { development program } \\
\text { of Kuno von } \\
\text { Klebelsberg, Minister of } \\
\text { Culture }\end{array}$ & & $\begin{array}{l}3.2 \text { worldwide } \\
\text { known } \\
\text { university } \\
\text { (mathematical } \\
\text { school of Alfréd, } \\
\text { Haar - Frigyes, } \\
\text { Reisz), Nobel } \\
\text { prizes of Albert, } \\
\text { Szent - Györgyi } \\
\text { (Vitamin C) }\end{array}$ & & & $\begin{array}{l}\text { 6.1 University } \\
\text { City - } \\
\text { appearance of } \\
\text { medical clinics, } \\
\text { collages, } \\
\text { university- } \\
\text { driven- } \\
\text { infrastructure }\end{array}$ \\
\hline $\begin{array}{l}\text { Period after } \\
\text { the World } \\
\text { War II. }\end{array}$ & $\begin{array}{l}1.7 \text { low level of central } \\
\text { development funds } \\
\text { provided, low level of } \\
\text { heavy industrial } \\
\text { installations, food } \\
\text { industry, industrial } \\
\text { hemp processing, } \\
\text { timber industry, brick } \\
\text { and tile manufacturing, } \\
\text { industry expansion both } \\
\text { in the '50s: furniture } \\
\text { production, garment } \\
\text { manufacturing and in } \\
\text { the '60s: cable } \\
\text { manufacturing, rubber } \\
\text { production, 1965: } \\
\text { exploration of } \\
\text { hydrocarbon fields, oil } \\
\text { zone, gas plant, building } \\
\text { industry }\end{array}$ & & $\begin{array}{l}\text { 3.3 Soviet } \\
\text { economic } \\
\text { system, weak } \\
\text { information } \\
\text { base, distortions }\end{array}$ & $\begin{array}{l}4.4 \text { production } \\
\text { to satisfy the } \\
\text { army's needs, } \\
\text { KGST } \\
\text { markets, } \\
\text { commerce of } \\
\text { furniture and } \\
\text { match } \\
\text { throughout the } \\
\text { country }\end{array}$ & & $\begin{array}{l}6.2 \text { green } \\
\text { spaces' } \\
\text { incorporating, } \\
\text { public work } \\
\text { management }\end{array}$ \\
\hline
\end{tabular}

Table 4: Evaluation system of sustainability for regional resilience analysis - dimension 'Society' (source: own compilation)

\begin{tabular}{|c|c|c|c|c|c|}
\hline & \multicolumn{5}{|l|}{ Society } \\
\hline & $\begin{array}{l}\text { 1. dominant } \\
\text { societal } \\
\text { groups }\end{array}$ & 2. employment & 3. features & 4. culture & 5. education \\
\hline $\begin{array}{l}\text { Period } \\
\text { between the } \\
\text { Roman Empire } \\
\text { and Hungarian } \\
\text { conquest }\end{array}$ & & & $\begin{array}{l}3.1 \text { after the fall of } \\
\text { The Empire of Huns } \\
\text { occupation by the } \\
\text { Gepids, Bulgarians, } \\
\text { Avars }\end{array}$ & & \\
\hline
\end{tabular}




\begin{tabular}{|l|l|l|l|l|}
\hline $\begin{array}{l}\text { Ottoman } \\
\text { Empire }\end{array}$ & & $\begin{array}{l}3.2 \text { discrimination } \\
\text { between Hungarians, } \\
\text { Turkish people }\end{array}$ & \\
\hline $\begin{array}{l}18^{\text {th }}-19^{\text {th }} \\
\text { Century }\end{array}$ & $\begin{array}{l}\text { 1.1 Piarists, } \\
\text { local } \\
\text { founders of } \\
\text { factories }\end{array}$ & $\begin{array}{l}2.1 \text { increasing level } \\
\text { on employment, } \\
\text { augmenting number } \\
\text { of workers at } \\
\text { factories }\end{array}$ & $\begin{array}{l}\text { 4.1 Piarists' } \\
\text { results: school } \\
\text { foundation, } \\
\text { theatre, providing } \\
\text { knowledge } \\
\text { transfer }\end{array}$ & \\
\hline $\begin{array}{l}\text { Period after } \\
\text { the World War } \\
\text { I. }\end{array}$ & $\begin{array}{l}\text { 2.2 high level of } \\
\text { unemployment }\end{array}$ & $\begin{array}{l}\text { 4.2: 1931, the } \\
\text { Votive Church of } \\
\text { Szeged becomes a } \\
\text { cathedral, Open- } \\
\text { Air Festival }\end{array}$ & \\
\hline $\begin{array}{l}\text { Period after } \\
\text { the World War } \\
\text { II. }\end{array}$ & $\begin{array}{l}1.2 \text { providing } \\
\text { jobs for } \\
\text { immigrants }\end{array}$ & 2.3 full employment & $\begin{array}{l}3.3 \text { priority of } \\
\text { society-driven goals }\end{array}$ & $\begin{array}{l}\text { 5.1 moving } \\
\text { the University } \\
\text { of Cluj- } \\
\text { Napoca to }\end{array}$ \\
\hline
\end{tabular}

Table 5: Evaluation system of sustainability for regional resilience analysis - dimension 'Institutional system' (source: own compilation)

\begin{tabular}{|c|c|c|}
\hline & \multicolumn{2}{|l|}{ Institutional system } \\
\hline & 1. Government & 2. Titles \\
\hline Roman Empire & $\begin{array}{l}1.1 \text { intermediary between Pannonia and Dacia, } \\
\text { border protection }\end{array}$ & \\
\hline $\begin{array}{l}\text { Period between the Roman } \\
\text { Empire and Hungarian } \\
\text { conquest }\end{array}$ & $\begin{array}{l}1.2 \text { situated next to the centre of the Hunnic } \\
\text { Empire }\end{array}$ & \\
\hline $\begin{array}{l}\text { The Hungarian conquest } \\
\text { and the Árpád Dynasty ( } 9^{\text {th }} \\
13^{\text {rd }} \text { Century) }\end{array}$ & $\begin{array}{l}1.3 \text { belonged to the ruling tribe's home in the age } \\
\text { of Conquest, and to The Roman Catholic } \\
\text { Archdiocese of Kalocsa at the reign of Stephen } \\
\text { I. }\end{array}$ & $\begin{array}{l}2.1 \text { got the title of city } \\
\text { from king Béla IV }\end{array}$ \\
\hline The $14^{\text {th }}-15^{\text {th }}$ Century & $\begin{array}{l}1.4 \text { administrative and military centre during the } \\
\text { reign of Matthias Corvinus }\end{array}$ & $\begin{array}{l}\text { 2.2 1498: Royal Free } \\
\text { City's title }\end{array}$ \\
\hline Ottoman Empire & 1.5 protection zone, garrison & \\
\hline $\begin{array}{l}\text { Period after the World War } \\
\text { I. }\end{array}$ & 1.6 becomes a diocese (centre of bishop) in 1931 & \\
\hline $\begin{array}{l}\text { Period after the World War } \\
\text { II. }\end{array}$ & 1.7 border cit & $\begin{array}{l}2.3 \text { centre of Csongrád } \\
\text { county since } 1962\end{array}$ \\
\hline
\end{tabular}

Table 6: Evaluation system of sustainability for regional resilience analysis - aggregated results (source: own compilation)

\begin{tabular}{|c|c|c|c|c|c|c|c|c|c|c|}
\hline $\begin{array}{l}\text { Sustainable } \\
\text { development } \\
\text { dimensions }\end{array}$ & No. & Category & \begin{tabular}{|l|} 
Roman \\
Empire
\end{tabular} & $\begin{array}{c}\text { Period } \\
\text { between the } \\
\text { Roman } \\
\text { Empire and } \\
\text { Hungarian } \\
\text { conquest }\end{array}$ & $\begin{array}{c}\text { The } \\
\text { Hungarian } \\
\text { conquest and } \\
\text { the Árpád } \\
\text { Dynasty ( } 9^{\text {th }} \text { - } \\
\text { 13 }\end{array}$ & $\begin{array}{l}\text { The } 14^{\text {th }} \\
-15^{\text {th }} \\
\text { Century }\end{array}$ & $\begin{array}{l}\text { Ottoman } \\
\text { Empire }\end{array}$ & $\begin{array}{c}18^{\text {th }}- \\
19^{\text {th }} \\
\text { Century }\end{array}$ & $\begin{array}{l}\text { Period } \\
\text { after } \\
\text { the } \\
\text { World } \\
\text { War I. }\end{array}$ & \begin{tabular}{|l} 
Period \\
after \\
the \\
World \\
War II.
\end{tabular} \\
\hline \multirow[t]{3}{*}{ Environment } & 1 & local resources & 1.1 & & 1.1 & $1.1,1.2$ & & $1.1,1.3$ & & $\begin{array}{l}1.4,1.5 \\
1.6,1.7\end{array}$ \\
\hline & 2 & $\begin{array}{l}\text { potential or } \\
\text { positional } \\
\text { resources }\end{array}$ & 2.1 & & 2.2 & 2.2 & & $\begin{array}{c}2.3,2.4, \\
2.5\end{array}$ & & \\
\hline & 3 & $\begin{array}{c}\text { environmental } \\
\text { impacts }\end{array}$ & & & & & & $3.1,3.2$ & & \\
\hline
\end{tabular}




\begin{tabular}{|c|c|c|c|c|c|c|c|c|c|c|}
\hline & 4 & $\begin{array}{c}\text { built } \\
\text { environment }\end{array}$ & & & & 4.1 & 4.2 & $\begin{array}{c}4.3,4.4 \\
4.5\end{array}$ & & 4.6 \\
\hline \multirow[t]{6}{*}{ Economy } & 1 & $\begin{array}{c}\text { economic } \\
\text { development }\end{array}$ & 1.1 & & 1.2 & 1.3 & 1.4 & 1.5 & 1.6 & 1.7 \\
\hline & 2 & prerogatives & & & 2.1 & 2.2 & & & & \\
\hline & 3 & knowledge & & & & & & 3.1 & 3.2 & 3.3 \\
\hline & 4 & supply & & & 4.1 & 4.2 & & 4.3 & & 4.4 \\
\hline & 5 & capital & & & & & & 5.1 & & \\
\hline & 6 & alteration & & & & & & & 6.1 & 6.2 \\
\hline \multirow[t]{5}{*}{ Society } & 1 & $\begin{array}{c}\text { dominant } \\
\text { societal groups }\end{array}$ & & & & & & 1.1 & & 1.2 \\
\hline & 2 & employment & & & & & & 2.1 & 2.2 & 2.3 \\
\hline & 3 & features & & 3.1 & & & 3.2 & & & 3.3 \\
\hline & 4 & culture & & & & & & 4.1 & 4.2 & \\
\hline & 5 & education & & & & & & & 5.1 & \\
\hline \multirow{2}{*}{$\begin{array}{l}\text { Institutional } \\
\text { system }\end{array}$} & 1 & government & 1.1 & 1.2 & 1.3 & 1.4 & 1.5 & & 1.6 & 1.7 \\
\hline & 2 & titles & & & 2.1 & 2.2 & & & & 2.3 \\
\hline
\end{tabular}

\section{Discussion}

During the history of Szeged city region both external shocks (Ottoman occupation, World Wars then the Soviet system) and internal shocks (the Great Flood and fall of the Soviet system and related markets) sharpened local economy. As Clark et al. (2010) and Howells (1999) emphasizes the importance of the strong regional system of innovation is major component of regional resilience: the presence of the university and its innovative potential is important factor with special respect to those inventions, innovations like the Nobel prizes of Albert, Szent-Györgyi for Vitamin C. After the collapse of the Soviet System due to the lack of innovative enterprises and knowledgebasin several factories, plants were closed and hit the local economy (Christopherson et al., 2010). It is a challenge in Hungary since nowadays how to fix the system after full occupation (typical during the Soviet regime) and unemployment still a crucial factor for handling. According to Archibugi \& Lundvall (2001) strength in factors, create a 'learning region' have positive synergy on adaptive capacity; which we could easily observe: during the economic development of the $18^{\text {th }}-19^{\text {th }}$ century, the invitation of the Piarists to the city region enhanced economic development: they founded school, acclimatized the theatre-games, and provided knowledge. Based on that knowledge and tradition between the first and second WW the first Open-Air Festival was organized which tradition lives until nowadays and makes the city popular on international level too. The city area as a learning region now participates in a project which European and could be stated Word-level significance: a new Research Infrastructure (RI) of panEuropean interest, part of the European ESFRI Roadmap called 'Extreme Light Infrastructure, ELI' is dedicated for for the investigation of light-matter interactions at highest intensities and shortest time scales. After a 3-year Preparatory Phase (2008-2010) of the ELI project, the ELI Consortium was set up, and on 11 April 2013 became the ELI Delivery Consortium International Association (ELI-DC AISBL). ELI is implemented as a distributed research infrastructure based initially on 3 specialised and complementary facilities located in the Czech Republic, Hungary and Romania. On 23rd 2017, the The Grand Opening Ceremony of ELI-ALPS in Szeged took place. Beside strong regional system of innovation, strength in factors that create a 'learning region', 
modern productive infrastructure (transport, broadband provision, etc.), skilled, innovative and entrepreneurial workforce, supportive financial system providing patient capital and finally a diversified economic base, not over-reliant on a single industry (Christopherson et al., 2010) are crucial factors: in the economic development before the World Wars these were factors in the city area for development: factory proprietors with international experience, introduction of the saving bank; while at the age of industrialization during the Soviet regime the commune of the unskilled workers' situation was unfavourable despite the fact that the city region was not so significant during that period because it did not have strong industrial focus. By this we can conclude, that when economic development if directly governed by the state or not based on the location's inner, endogenous resources, capital it blocks its adaptive capacity. The vulnerability also increases in the absence of diversified economic structure. According to Christopherson et al. (2010) the likelihood of success being sustained over the long term will depend crucially on its ability to adapt to changing circumstances over time and to adjust to external shocks as and when these occur: in case of the city a good example of the emblematic factory 'Pick' with flagship product of our company is the world-famous PICK Original Wintersalami, an uniquely Hungarian product has been made according to the original secret recipe of Márk Pick for over 147 years after. The Factory also a good case for the description of Simmie and Martin (2010) since they interpret resilience as 'adaptive ability': the differential ability of a region's or locality's firms to adopt to changes and shocks in competitive, market, technological, policy and related conditions that shape the evolutionary dynamics and trajectories of that regional or local economy over time. There is common understanding, that in the next years the ELI could be the breaking point for the enhancing the local business' environment. We can observe the interrelated dimensions of Martin (2012) in the history of the city region: resistance, recovery, re-orientation and renewal. The example of the Pick factory for resistance, the recovery both in physical circumstances after the Great Flood, Wars and in human/ scientific manner with the ascending importance of the university in the viability of the city area; re-orientation during the conjuncture in the age of Austro-Hungarian Compromise with the growing number of enterprises, factories or after the World Wars; and finally the renewal for which the developments after the Ottoman occupation and fall of the Soviet system provides good case. And finally, the most well-known interpretation of regional resilience, the ' $4 \mathrm{R}$ ' approach, which significance is that it highlights the multiple paths to resilience and directs to look beyond physical and organizational systems to the impact of the chock on social and economic systems (Palekiene et al., 2015): robustness, redundancy, resourcefulness and rapidity also played importance role for the long-term viability of the city region: even during the Soviet system the city was able to partly preserve its structure based on food-production and after the fall the economic branch was able to renew; it was able to respond to disturbance by overcoming dependence by deferring, using substitutes both at the age of Ottoman occupation and Soviet regime. The relatively quick reconstruction after the great flood of 1879, which literally wiped away the whole town, caused a pause in the city's development, but later on the reconstruction of the city resulted a radial urban structure, and the city was given a residential character is the good example of resourcefulness, since the city region had 
capacity to mobilize and apply material and human resources to achieve goals in the events of disruptions and rapidity too.

The analysis have carried out that continuous development criterion links regional resilience to sustainable development (improve the lives of people round the World) and in future research there must be emphasis on enhancing economic development either by policies, fund allocation or just creating the framework from resilience point of view, in which sustainable development must receive special emphasis.

\section{References}

Armstrong, H.W. (1995). Convergence among Regions of the European Union: 1950-1990. Papers in Regional Science, 74(2), pp. 143-152. doi:10.1111/j.1435-5597.1995.tb00633.x

Bhagwati, J.N., Krueger, A.O. (1973). Exchange Control, Liberalization, and Economic Development. The American Economic Review, 63(2), pp. 419-427.

Blazovich, L. (eds.) [2010]: History of Szeged, no. 5. 1945-1990 'Szeged története 5 1945-1990' in Hungarian. Agapé, Ferences Nyomda és Könyvkiadó Kft. After digitalization it is available at: http://www.sulinet.hu/oroksegtar/data/telepulesek_ertekei/szeged/szeged_tortenete_5/, downloaded: $31^{\text {st }}$ October, 2012.

Bruneau, M., Chang, S., Eguchi, R., Lee, G., O’Rourke, T., Reinhorn, A., Shinozuka, M., Tierney, K., Wallace, W., von Winterfelt, D. (2003). A Framework to Quantitatively Assess and Enhance the Seismic Resilience of Communities. EERI Spectra Journal 19(4), pp.733-752

Buckle, P., Mars, G., Smale, S. (2000): New Approaches to Assessing Vulnerability and Resilience. Australian Journal of Emergency Management 15(2)

Christopherson, S., Michie, J., Tyler, P. (2010). Regional resilience: theoretical and empirical perspectives. Cambridge Journal of Regions, Economy and Society 2010(3), 3-10. doi:10.1093/cjres/rsq004

Csete, M., Szabó, M. (2015). Pole cities: economic development enhancers and limits. Case of two Hungarian regional centres. Economic Annals-XXI (2015), 3-4(1), 97-100.

Daragó, S. (2008): History of Szeged 'Szeged története' in Hungarian. Available at: http://szeged.network.hu/blog/szeged_klub_hirei/szeged_tortenete, downloaded: $20^{\text {th }}$ of July, 2017.

Dawkins, C.J. (2003). Regional Development Theory: Conceptual Foundations, Classic Works, and Recent Developments, Journal of Planning Literature, 18(2), available at: http:/ / citeseerx.ist.psu.edu/viewdoc/download?doi=10.1.1.197.6878\&rep=rep1\&type=pdf, downloaded: $19^{\text {th }}$ July, 2017.

Drexhage, J., Murphy, D. on behalf of International Institute for Sustainable Development (IISD) (2010): Sustainable Development: From Brundtland to Rio 2012. Available at: http://www.surdurulebilirkalkinma.gov.tr/wp-

content/uploads/2016/06/Background_on_Sustainable_Development.pdf, downloaded: $13^{\text {th }}$ July, 2017.

Martin, R. (2012). Regional economic resilience, hysteresis and recessionary shocks. Journal of Economic Geography 12(1), 1-32.

Palekiene, O., Simanaviciene, Z., Bruneckiene, J. (2015). The application of resilience concept in the regional development context. Procedia - Social and Behavioral Sciences 2015(213), 179 - 184.

Parliament of Hungary (2013). Resolution 18/2013. (28 th March) of the Parliament on the National Framework Strategy on Sustainable Development 2012-2024 [Framework Strategy].

Pálvölgyi T., Czira T. R. Pongrácz, R. (2011). Climate change vulnerability. In: CLIMATE CHANGE - 2011 Climate Scenarios in the region of Carpathian Basin. eds.: Bartholy J., Bozó L. and Haszpra L. ISBN 978-963-284-232-5 . Hungarian Academy of Sciences - Eötvös Lorand University, Dept. of Meteorology.

Reizner, J. (1899): History of Szeged 'Szeged Története' in Hungarian. Szeged szabad királyi város közönsége (Audience of Royal Free City), 1899, Szeged. http://www.bibl.u-szeged.hu/reizner/index2.html, downloaded: 27th October, 2012. 
Simmie, J., Martin, R. (2010). The economic resilience of regions: towards and evolutionary approach. Cambridge Journal of Regions, Economy and Society 2010 (3), 27-43. doi: 10.1093/cjres/rsp029

Tu, C., Chen, B. (2013): New Measurement Methods of Network Robustness and Response Ability via Microarray Data. PLoS ONE 8(1). doi: e55230. https://doi.org/10.1371/journal.pone.0055230

United Nations Sustainable Development Knowledge Platform [UN SDKP] (online). Sustainable Development Goals. Available at: https://sustainabledevelopment.un.org/focussdgs.html, downloaded: $18^{\text {th }}$ July, 2017.

Van Der Veen, A., Logtmeijer, C. (2005): Economic Hotspots: Visualizing Vulnerability to Flooding. Natural Hazards 36(1-2), 65-80.

World Commission on Environment and Development [WCED] (1987). Our Common Future. Oxford: Oxford University Press. 